\title{
Valuation and Service Trusts
}

\section{Ian Fargher ${ }^{1}$}

\begin{abstract}
The oblique nature of control over assets of a trust has always been challenging when personal asset distribution is at issue. This is no more apparent than in the context of Family Law. Complex organisational arrangements may make sense when considering tax planning or asset protection strategies, however, they may present difficulties for the application of sections 79 and 75 of the Family Law Act 1975.
\end{abstract}

Specific difficulties are experienced when dissecting the economic structures of professionals, where the issues of professional and business intangible assets and tangible assets are held within service trust structures, intertwined with personal professional wages, incorporated professional entities, professional distributions and family distributions. Service trust arrangements have become popular for Australian professionals, such as, doctors, accountants, lawyers and engineers due to their tax effectiveness which passed the court's test in the 1978 case FCT $v$ Phillips. The Australian Taxation Office (ATO) has issued 'safe harbour' rules for the operation of service trust arrangements which may provide some, in principle, assistance to Family Law decision making.

This paper investigates the Family Law issues with respect to partner distributions where a service trust structure is in place. In this regard, the paper considers the business structuring concepts including the rights and roles of those associated with trusts, particularly the exercising of control. Secondly, the paper reviews the courts decisions with respect to looking through business trust structures with reference to the reasoning expressed in past judgements. Finally, the paper considers the Family Law distribution effects of tangible and intangible assets when professional services are encased within a Philips Trust type structure.

This paper should be of interest to those involved, or potentially involved, in Family Law asset distribution. Specifically, legal and professional advisors, such as lawyers, accountants and valuation professionals. The paper's objective is to assist in clarifying the complex issues of understanding business structures underpinning the transaction based cash flows between entities and their potentially intertwined equity.

JEL classification: K34, K41, M40

Keywords: Taxation, Australia, Valuation, Service Trusts.

\footnotetext{
${ }^{1}$ University of Wollongong, Australia.
} 


\section{Introduction}

The desire to minimise tax is a common driver of commercial behaviour in Australia (Jenkin, 2006; Kane, L. 2016; Janda, M. 2017, Brown M. 2016, Boucher, T. 2010, Pagone, T. 2010). This is no more apparent than where individuals and businesses have higher earning capacity, such as, with respect to the delivery of professional services to end consumers (see Professionals Australia, 2019). Specifically, where a professional earns a high income then there is an incentive to divert some of that income to associated entities or individuals where the rate of taxation per dollar earned is reduced (marginal rate $^{2}$ ).

This paper briefly reflects on the tax planning incentives that give rise to tax effective business structures before discussing their importance in the valuation context. That is, an economic structure is primarily compiled for tax effective and asset protection reasons ${ }^{3}$ with little consideration of its implications in the context of valuation. The need for valuation often arises for the purposes of family law, a context rarely considered when constructing the economic business structure.

The paper then reviews a common tax effective structure used by professionals to effectively distribute wealth within a family unit. Known as a service trust structure, or alternatively a Phillips trust structure after the 1978 case FCT $v$ Phillips, the paper describes the purpose and operation of the entity connections within the structure in accordance with the acceptable standards articulated by the Australian Taxation Office (ATO) that are in common use for professional businesses ${ }^{4}$. The description includes the connection between a primary income generating individual (a professional), a company, a family trust and individuals as beneficiaries. The flow of income, its purpose and effect are noted before the context is moved from tax effectiveness to valuation with specific emphasis on family law. The valuation context provides certain difficulties particularly around the trust distributions where the issue of effective control and professional goodwill need to be addressed.

In conclusion, the choice of appropriate valuation methods is considered and related to family law purposes. The importance of considering confirming valuation methods and the "value to the owner' concept is noted.

\footnotetext{
${ }^{2}$ The marginal rate of tax is that tax rate applied to the next dollar of taxable income that is earned, each additional dollar of income. (see www.investopedia.com/terms $/ \mathrm{m} /$ marginaltaxrate.asp).

${ }^{3}$ This is despite the 'official wise' version of creation of trusts being for business succession planning and estate planning.

${ }^{4}$ The ATO describes a service trust structure within a 'safe harbour' context, such that, if professionals use the structure within the limits the ATO describes, then the professional (and associates) will not be pursued by the ATO for additional tax obligations. Therefore, the structure as described is in common commercial use, marketed through accounting and legal firms with the confidence of a complying structure (see, for example, https://www.legalconsolidated.com.au/service-trust-agreement-intro/).
} 


\section{Australian Tax}

The Australian income tax system is based upon progressive tax principles ${ }^{5}$ where it is expected that those with the capacity to earn more, pay more tax, contributing proportionally more to the funding of government and public resources (www.austaxpolicy.com/brief-progressive-andregressive-taxes/). This is evident in the sliding personal tax rate that increases across tax brackets as indicated in Table 1. Taxable income earned within the financial period (1 July in year $\mathrm{xxx} 1$ to 30 June $\mathrm{xxx} 2$ ) is eventually allocated to either an individual who pays tax according to the appropriate tax bracket or a company that pays tax according to its corporate tax rate $^{6}$ (Table 2). Income may flow through various entity structures (such as trusts) before paying tax as a company or individual.

\begin{tabular}{|l|l|}
\hline \multicolumn{2}{|l|}{ Table 1: Resident Individual Tax Brackets and Progressive Tax Rates for 2020} \\
\hline Taxable income & \multicolumn{1}{|c|}{ Tax on this income } \\
\hline $0-\$ 18,200$ & Nil \\
\hline$\$ 18,201-\$ 37,000$ & $19 c$ for each $\$ 1$ over $\$ 18,200$ \\
\hline$\$ 37,001-\$ 90,000$ & $\$ 3,572$ plus $32.5 c$ for each $\$ 1$ over $\$ 37,000$ \\
\hline$\$ 90,001-\$ 180,000$ & $\$ 20,797$ plus $37 \mathrm{c}$ for each $\$ 1$ over $\$ 90,000$ \\
\hline$\$ 180,001$ and over & $\$ 54,097$ plus 45 c for each $\$ 1$ over $\$ 180,000$ \\
\hline
\end{tabular}

\footnotetext{
${ }^{5}$ The Australian taxation system for individual taxpayers is said to be progressive because it applies higher tax rates to those who earn higher taxable income. For example, an individual on a low income pays little or no income tax, whereas an individual on a high income pays a high marginal rate of tax, such as 47\%. (see www.austaxpolicy.com/brief-progressive-and-regressive-taxes/)

${ }^{6}$ The tax on taxable company profits is assessed at a flat rate of $28.5 \%$ for smaller businesses $(<\$ 50$ mil annual turnover) and $30 \%$ on larger businesses.
} 


\begin{tabular}{|l|l|}
\hline Table 2: Corporate flat tax rates & \\
\hline Income category & Rate $(\%)$ \\
\hline Base rate entities (turnover $<\$ 50$ mil per annum) & 27.5 \\
\hline Otherwise & 30 \\
\hline
\end{tabular}

Once tax is paid on individual income, the after tax money, is available for personal use. An individual pays tax at the marginal rate as shown in the Table 1 examples. The amount of tax paid on the next dollar earnt is called the marginal tax rate (Investopedia.com). Tax paid on corporate income by the company is paid at a flat rate, however, the money belongs to the company. The company can then distribute the money to shareholders in the form of dividends. Dividends may include franking credits ${ }^{7}$ for the tax paid by the company. Dividends and franking credits received by resident individuals are taxed as part of an individual's total annual income.

All taxpayers have the right to manage their tax affairs within the law. The Australian tax acts, The Income Tax Assessment Act 1936 (ITAA 36) and The Income Tax Assessment Act 1996 (ITAA96) (together 'the Tax Acts') together with the Tax Administration Act 1953 (TAA 53) set out a taxpayer's taxation obligations. The acts are complex, an issue that is neither new, nor unique to Australia (Carmody, 2004; Garran, 1958, Commissioner of Taxation Annual Report, 1990-91). The Tax Acts are subject to a long history of legal interpretation and bureaucratic advice, of which only the very basic description will be provided in this paper, as is relevant to the issues at hand. However, as a principle it is important to note that an individual has the right to manage their tax affairs in the most beneficial manner, within the law. This is referred to as tax planning or even extended to tax avoidance, where the tax planning may be deemed to 'stretch' the law, for example, where a decision may not concur with the law's intent but may be within the 'letter of the law'. On the other hand tax evasion, where the law is broken or tax obligations are deliberately not fulfilled, is illegal.

Tax planning often involves a layered structure of entities, where income can be channelled through one entity to another, taking advantage of intentional or unintentional legal or administrative differences. For example, if income can be channelled from an individual on the top marginal rate of $47 \%$ including Medicare (2\%) to a company on a flat rate of $27.5 \%$, then,

7 A franking credit, also known as an imputation credit, is a type of tax credit paid by corporations to their shareholders along with their dividend payments. Australia and several other countries allow franking credits as a way to reduce or eliminate double taxation on corporate profits or individual income (www.investopedia.com/terms/f/frankingcredit.asp). 
there is a tax advantage of $19.5 \%$. If an entity structure can funnel income from a high income earner, with a marginal rate of $45 \%$ to another, perhaps associated, individual on a lower marginal tax rate, such as, below the income tax threshold $(0 \%)$ or even at $32.5 \%$ then, again, there is a substantial tax saving incentive to be derived from the creation and use of an accommodating business structure. Professionals, such as, medical doctors or lawyers generally have the capacity to earn significant income, often well above the highest marginal rate threshold, and therefore there is an incentive for them to distribute before tax income to associates (such as family members) whose tax obligations have excess earning capacity. The Australian tax system also has a legislatively specified advisory level (registered taxation agents) whose role is to advise and facilitate taxpayer's in the fulfilment of their tax obligations. These registered tax agents are professionally qualified and subject to their own set of rules and obligations to act within the law (Tax Agent Services Act, 2009). Many such agent avail their expertise to arrange and manage multi entity layered business structures (Thompsonhall, 2019; Legal Consolidated Barristers and Solicitors, 2019; TaxEffective Accountants, 2020)

The Australian Taxation Office ('ATO') warns that:

Tax planning is legitimate when you do it within the intent of the law. However tax minimisation schemes that are outside the spirit of the law may attract our attention. We refer to these as tax avoidance schemes or arrangements.

A tax avoidance scheme involves the deliberate exploitation of our tax and superannuation systems. We take these schemes seriously, and will take action when they are not lawful.

\section{https://www.ato.gov.au/General/Tax-planning/}

The ATO is tasked with the bureaucratic implementation of the tax laws ${ }^{8}$, however, by practical necessity, it sometimes extends this remit to straddle the interpretation of potential judicial matters (as an alternative to the expensive process of taking a matter to court). This activity is driven by the need for taxpayers to have confidence that their tax decisions do not cross outside the boundaries of proper tax planning, putting earnings at risk of additional taxation and penalties. The ATO's advice is given in a range of guidance products from taxpayer alerts and practical compliance guidance to interpretive decisions and administrative practice statements (see www.ato.gov.au/General/ATO-advice-and-guidance/ATO-guidance-products/; PS LA 2008/3) Often the ATO's advice follows seminal taxation cases decided by the judiciary, where the tax office and taxpayers wish to avoid the expense of repeated litigation. The Commissioner publishes his opinion on how a tax law would apply in a statement known as a public ruling usually referenced in the 'TR' series. "Public rulings provide advice for taxpayers, their advisers and ATO personnel on the interpretation of tax laws that affect liability or entitlements under those laws. In addition, public rulings can address administrative and procedural provisions, including those relating to the collection of liabilities" (ATO, 2008, p29).

\footnotetext{
${ }^{8}$ This is a reference to the bureaucratic role of the executive in government and the public service as against the legislative role of parliament and the interpretive role of the judiciary.
} 
With regard to the issue of tax structuring using layered entities the seminal judicial decision issued in FTC v Phillips (1978) and IT 276 has been expanded in TR 2006/2 (Income tax: deductibility of service fees paid to associated service entities: Phillips arrangements) (herein referred to as 'service trust' or 'Phillips' arrangements). As discussed, although not formally admitted, the tax driven incentive to structure professional businesses in accordance with the design set out and discussed in TR 2006/2 has been widely promoted and adopted. It is therefore appropriate to consider the ATO approved version of Phillips arrangements even though the tax office's focus on the deductibility of service fees varies from the valuation focus of this paper. Of particular relevance to both taxation and valuation is the consideration of the market price for the services provided by the service entity.

\section{Service Entity or Phillips tax planning structures}

In essence, a service entity arrangement involves a taxpayer incurring a deduction for fees and charges in the conduct of its business, with the entity that provides the services for the deduction being associated with the taxpayer and producing an income from the provision of the services to the taxpayer. The services provided are usually for the acquisition of staff, clerical and administrative services, plant and equipment. The seven indicative attributes set out in TR 2006/2 are:

a) the taxpayer, being an individual or an entity, carries on a business, alone or in partnership, for the supply of professional or other services to clients;

b) there is a trust that is controlled, or a company that is owned and/or controlled, by the taxpayer and/or associates of the taxpayer (the service entity);

c) the taxpayer, alone or in partnership, enters into an agreement with the service entity whereby the taxpayer agrees to pay certain fees and charges to the service entity in return for the service entity supplying the taxpayer with a range of services which may include: staff hire and recruitment services, clerical and administrative services, premises, plant and/or equipment;

d) typically, the service fees and charges are calculated by way of a mark-up on some or all of the costs of the service entity (although a fixed charge may be agreed by the parties upfront);

e) the taxpayer claims a deduction for the service fees and charges as expenditure incurred by it in the conduct of its business;

f) the service arrangement either gives rise to profits in the service entity, for both accounting and tax purposes, or would give rise to profits in the service entity but for remuneration or service fees paid to associates of the taxpayer or the taxpayer's partners; and

g) the profits derived by the service entity are either retained by the service entity (usually where the service entity is a company) or distributed, directly or indirectly, to the taxpayer (and its partners in the case of a partnership) and/or to associates of the taxpayer (and associates of its partners in the case of a partnership).

Of significance is the acceptance in Phillips that these attributes were "a re-arrangement of business affairs for commercial reasons and realistic charges, not in excess of commercial rates". TR 2006/2 further notes that: 
8. Ordinarily, expenditure incurred in obtaining the supply of goods or services from another party under a contract will be characterised by reference to the contractual benefits passing to the taxpayer under the contract and the relationship that those benefits have to the taxpayer's income earning activities or business.

9. This means that where the benefits conferred by a service arrangement provide an objective commercial explanation for the whole of the expenditure made under the service arrangement, then the service arrangement alone will suffice to characterise the expenditure as expenditure that satisfies the positive limbs of section 8-1 of the ITAA 1997.

TR $2006 / 2 \sec 8 \& 9$

Whilst the ruling discusses the detail of particular expenses, it is the nature of the service entity that is of most relevance to the valuation exercise. For the purpose of this paper it is accepted that the service entity provides appropriate services conducive to the production of assessable income by the individual or group of professionals. The accepted service entity structure has a service entity set up and operated in a commercial manner, distinct from the taxpayer, usually a high earning professional trading as an individual or as a partnership with similar high earning professionals. Diagram 1 sets out a schematic representation of a typical service entity structure. 
AABFJ | Volume 14, No.5, 2020

\section{Diagram 1: Typical Service Entity Structure}

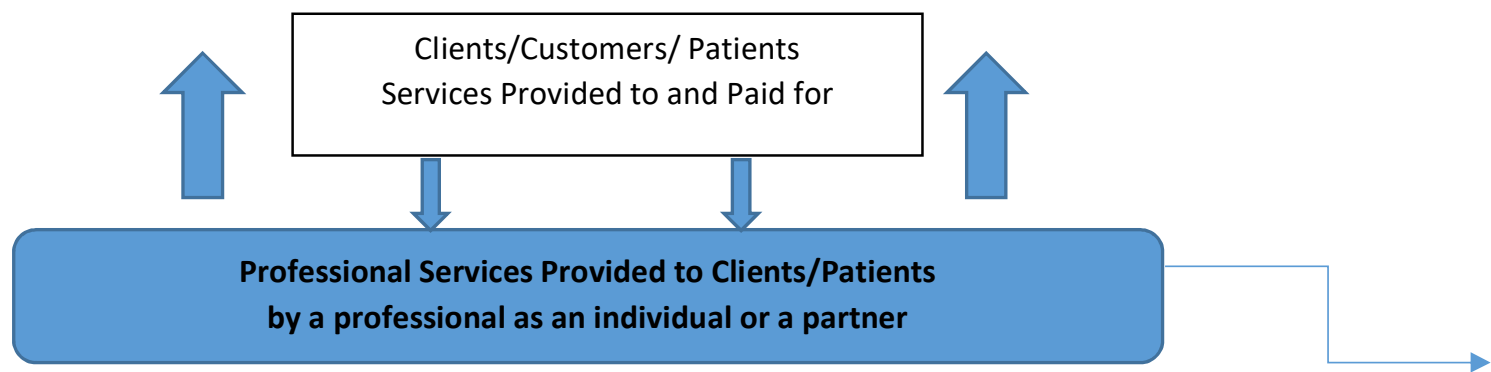

Service entity has an agreement to provide services to the professionals

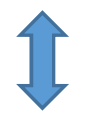

Service entity - either a Company or Fixed Trust with unitary ownership in shares of trust units

Provides support and infrastructure services to the professional business at a commercial rate including profit
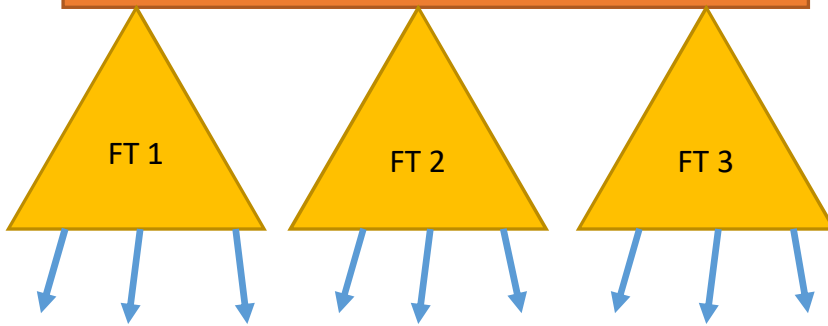

Professional earns a salary and declares the salary as personal earnings Not alienable or capitalisable

The service entity has fixed ownership that is saleable. Ownership is usually through a Family Trust with each professional in the partnership having their family trust sharing in the ownership of the service entity

Beneficiaries that can receive a distribution from the family trust as decided at the trustee's discretion. The family trust is usually defined by the family of the professional in the partnership or sole trader. 


\section{Valuation of income earning entity}

In the example outlined above there are three sets of income earning entities (although not necessarily tax paying entities). Firstly there is the professional earning income either directly as an individual or as a member of a professional partnership. These earnings are in the form of wages and salary, in that they are received regularly and are directly dependent on the professional doing their work to provide the specialised professional service, such as, attending appointments or conducting procedures. From a valuation viewpoint these earnings are not alienable and therefore not capitalisable. They are an indication of future salary capacity.

The second level of income is earned by the service entity for the provision of selected services to the professionals that are necessary for the professionals to undertake their work. For example, where the professional is a general practice doctor the service entity might provide on-site nursing staff, reception and clerical staff, financial/billing software, fixtures and fittings. In an ATO acceptable form this service is provided at commercially realistic rates which include a reasonable profit for the service entity. Ownership or control of the service entity requires no special attributes and the ownership is alienable, in that, it can be transferred through the transfer of equity instruments, such as, shares in the service company, or units in a unit trust. Shares or units have defined rights and can be transferred by, for example, sale or gift.

The third level of income is received by the owners of the equity instruments in the service entity. The actual flow of income is dependent on the entity holding the equity instrument. The rights of the holding entity may be defined (such as, for a beneficially held ordinary share) or they may be subject to some discretion (such as the position of a beneficiary of a family trust). In this regard, valuation matters may depend on issues of trust control which, although they are matters for the Court, will be considered as this paper progresses.

\section{Valuation of the service entity}

The service entity is structured to have a unitised equity, fixed to enable an expected distribution of profits usually by consistent share rights (for example, ordinary shares) or by unit rights to a fixed profit share in a unit trust. These rights are alienable and can be traded, therefore they have a value for the owner. The issue then is, what is the value of the service trust? Once answered, the value can be distributed according to the share or unit rights.

If the service entity is a proprietary limited company its equity will be defined by shareholding based on the rights of specific types of shares. The shareholding, including types of shares, should be available on the Australian Securities and Investment Commission's (ASIC) company register. Most companies only have ordinary shares with equal voting and equity rights, proportional to shareholding. Other shares can have a mix of voting and equity rights, sometimes with specific conditions. If a service entity in a Phillips structure is a company its shareholding is usually proportional to the professional's control or wishes. The tax advantage of a company providing chargeable services is that it pays only company tax and the assets of the company are protected within the company structure. The drawbacks of having a company provide the commercial service function is that the profits earned by the company remain the property of the company and must be distributed, via dividends, before they can be used for private purposes. 
If the service entity is a trust it is usually a fixed trust where the trustee holds the trust assets for the benefit of specific beneficiaries in certain fixed proportions. More specifically these trusts are usually unit trusts where the beneficiaries are identified by their holding of units in the trust, much the same as shares are issued to shareholders of a company. Beneficiaries can transfer their interests in the trust by transferring their units to another entity by sale or gift (Garry 2019). Units are usually allocated to the service entity in conjunction with the individual professional or professional partnership's concurrence.

Valuing the service entity is a process not materially different from the valuation of any small to medium entity with a similar customer base. In this regard, the customer base is usually contracted (for a fixed percentage of accepted rate per service) or strongly linked to the primary source of income (the professional's client/patient fees) through co-location. Equities in the service entity are not likely to have an open market with their sale often representing minority interests or linked to the provision of the professional salaried services". In this regard the 'value to the owner' concept must be kept in mind for family law valuations. The service business is likely to be profitable, with little initial or retained equity because the tax structure has been set up to distribute income to more tax effective end users. Nevertheless the balance sheet equity should be considered on its real value. The Future Maintainable Earnings (FME) methodology is probably the most appropriate and generally utilised to establish the capitalised value of small to medium entities where the business is not currently being brought to market, is a going concern and there is no established market for the business' securities.

The FME method, based on the capitalisation of extended, normalised profit, should produce an overall value of what an independent, fully informed investor would pay to acquire the business given the circumstances coinciding with those used to calculate the risk factor used in the capitalisation process. This should include the value of tangible and intangible assets. Of particular note is any intangible asset, particularly with the concept of "goodwill", "professional goodwill" and "brand".

Goodwill accounts for the excess purchase value of business after the fair value of the tangible (and other intangible) assets less liabilities that have been accounted for. Goodwill is over and above other intangible assets that can be specifically identified and separated, such as, brand recognition, licensing or legal rights that can be passed on in the form of a contract.

Brand value is the (premium) future cash flows produced by the differentiation delivered through recognition of a constant and consistent delivery of a promise. It is often represented through a business name or logo and is essentially built on past performance and promotion. The service entity may have brand value, particularly if it owns a recognisable trading name or provides excellence in service not linked to a particular professional provider (for example, when the professional provider can be replaced, but, clients would continue to conduct business with the entity under the comfort of the recognised trading name).

\footnotetext{
${ }^{9}$ In this regard, the link is not indelible as there is no reason that there cannot be a choice between the provision of a professional service alone and the provision of a professional service and the 'control' of the service entity equity.
} 
Professional goodwill is the value attached to the personal efforts of the professional, where the future revenue stream depends significantly on the personal efforts of that professional. For example, where a professional is of particular eminence or has a distinctive local reputation. This may be of relevance in assessing the value of the business structure, however, as the service entity structure deliberately isolates the professional's earnings from the provision of professional services, so too is the professional goodwill attached to the professional isolated from the service entity. Nonetheless, if an eminent professional is replaced by a far less recognised professional, then the revenue the new professional brings in may well be reduced and reflected in the service entity's revenue.

In this regard, the value of the service entity needs to be carefully considered with respect to the revenue linkages between the professional and the service entity. By construction the service entity charges at commercial rates, most often built up on a cost plus margin basis. In this instance the service entity's charges to the professional either as an individual or partnership are not linked to the professional's earning capacity (beyond the ability to pay for the services provided). Therefore, the additional earning capacity generated by the professional is reflected in the professional's salary received as a sole trader or partner. If the service entity earns income on the basis of a percentage of the professional's income, then the service entity's revenue may be affected by a less eminent successor. Nevertheless, the service entity's income is not directly linked to the professional's goodwill, but the potential future cash flows for the service entity which should be mitigated either in quantification (such as applying a discount) or through risk recognition in the capitalisation factor of the FME process (that is, including a higher risk that the expected future cashflows will be less than expected). The service entity's value may be indirectly affected through reduced future financial performance, however, the value is not extinguished in favour of the professional's personal goodwill. There is no personal attachment to the commercial provision of the services.

\section{Valuation of the service entity equity holders}

The third level of the economic structure is where the income is eventually channelled. At this point flexibility is the main factor, such that, income can be disbursed in the most tax effective manner. This is usually achieved through the use of a discretionary trust, often a family trust is utilised for even greater tax effectiveness. In a family trust ${ }^{10}$ the beneficiaries are the family members (defined somewhat broadly by the ATO) and they will most likely have tax positions that vary between each beneficiary and fluctuate over time. The ability for a trustee to channel income to a range of beneficiaries each year opens up opportunities to save tax, but also presents difficulties for the valuation process because the parties involved in the business do not have any beneficial interest in the business (in the trust) until they become presently entitled. That is, before the trustee grants a distribution to a beneficiary, the beneficiary has no rights to the earnings of the discretionary trust, which in this case arise from the business of providing professional services.

The court, particularly under family law, is often interested in the valuation of the professional's business, which under the economic structure becomes a question of how the professional deploys

\footnotetext{
${ }^{10}$ A family trust is basically a discretionary trust that has taken a family trust election for taxation purposes. A family trust election gives the trust some additional taxation and administrative benefits.
} 
their earnings through salary, service payments and family trust distributions. Whilst this appears complex, the colloquial version that "it is all the professional's money" expresses a basic logic, perhaps at variance to the rules pertaining to each level of the economic segmentation. Reflection on the purpose for financial structuring does not materially assist the valuer's task of clarifying the professional's worth. Assets are owned by the entities themselves, such as, the company, the unit trust and the discretionary trust. This is particularly relevant for a discretionary trust.

\section{Property of discretionary trusts}

Strictly, the property is not the property of the parties to the marriage, however, the Court is not limited in its ability to exercise jurisdiction to deal with the property of the trust. In this regard the following discussion will consider how the Court deals with discretionary trusts, particularly with respect to family trusts in the context of family law distributions. Such consideration is primarily the domain of the lawyers, however, it is of material interest to accountants and valuers, in that, they may better advise the Court in the recognition of trust complexities.

A discretionary trust, in Australian and English law, is "a trust where the beneficiaries and/or their entitlements to the trust fund are not fixed, but are determined by the criteria set out in the trust instrument (deed) by the settlor and the trustee who has the latitude or discretion to give or deny the beneficiary benefits under the trust." (www.businessdictionary.com; see also Gartside v IRC 1968; RE Weir's Settlement, 1969 and Sainsbury v IRC 1970). A discretionary trust can be exhaustive (distributes all revenue) or non-exhaustive (is not compelled to distribute all revenue ${ }^{11}$ ) The trust is set up by a settlor investing money into the trust as set out in a trust deed which broadly describes the purpose, structure and type of trust, including any special conditions informing the operation of the trust or trustee. A trustee is appointed to administer the trust. The trustee may be an individual, more than one individual or a corporation (in which case the directors of the corporation make the trustee decisions). An appointer may also be nominated who can remove or replace the trustee. In a service entity situation with a family trust it is common for the professional to be the nominated family person and/or the trustee (or director of the trustee company) and/or the appointor. The trust distributes net revenue to its beneficiaries who may include the professional.

A common version of a discretionary trust is a family trust which, for tax purposes, is a discretionary trust that has made a family trust election. The structure of a family trust is such that the beneficiaries are defined, and limited to the family of a specified individual (usually the professional in the economic grouping that has been considered here).

The Family Law Act 1975 ("the Act") allows the Court to allocate properties between the parties to a marriage when separating. Specifically, sec 79(1) of the Act grants the power to alter the interests of all of the parties in the property. Section 79(1) states:

In proceedings with respect to the property of the parties to a marriage...the Court may make such order as it considers appropriate altering the interests of the

\footnotetext{
${ }^{11}$ Although in Australia the taxable income held by the discretionary trust for that tax year is subject to the highest individual rate of tax plus Medicare (currently 47\%) so there is a significant incentive to distribute tax income to beneficiaries on a lower marginal tax rate.
} 
parties in the property, including an order for a settlement of property in substitution of any interest in the property and including an order requiring either or both of the parties to make, for the benefit of either or both of the parties or a child of the marriage, such settlement or transfer of property as the Court determines.

Further property is defined as:

Property in relation to the parties to a marriage or either of them means property to which those parties are, or that party is, as the case may be, entitled whether in possession or reversion. $\quad \mathrm{Sec}$ 4(1)

The Family Court has found that property had a broad meaning stating that:

We are of the view that the intention of $\mathrm{s} 79$ is to enable the court to take into account and assess all the property of the parties upon being asked by either of them to make an order altering the interests of the parties in the property. We are further of the view that where $\mathrm{s} 4$ defines property as being 'property to which the parties are entitled whether in possession or reversion.

Duff and Duff (1997)

Examples of the application of this broad definition of property (see also French CJ in Kennon $\mathrm{v}$ Spry, 2008) include an interest in a partnership, a claim in a proprietary fund held in a fixed trust and a party's interest under a trust, depending on the nature of the interest and the degree of control (Broun and Fowler, 2016 pp 36, 110).

Section 79(4) sets out the factors which should be considered when making property orders with respect to a marriage. These can be put into two groups being the contributions made to the accumulation of marital assets ( $\sec 79$ (a), (b), and (c)) and the current and future needs of the parties to and issue of the marriage (sec 75(2); sec 79(4)(e); sec 79(d) (f) (g). Section 79(2) of the Act also provides that the Court "Shall not make an order under this Section unless it is satisfied that, in all of the circumstances, it is just and equitable to make the order". This offers the Court significant latitude when dealing with a property adjustment (Mellas, 2016; see also Hickey and Hickey, 2003).

This four step property decision process is an activity for the Court, however, it is useful context for the valuer providing expert witness testimony to recognise the basic consideration. Specifically in Stanford and Stanford, 2012, the High Court stated:

First, it is necessary to begin consideration of whether it is just and equitable to make a property settlement order by identifying, according to ordinary common law and equitable principles, the existing legal and equitable interests of the parties in the property...... The question posed by s79(2) is thus whether, having regard to those existing interests, the court is satisfied that it is just and equitable to make a property settlement order. 


\section{Discretionary Trusts and Control}

As noted earlier discretionary trusts can present a problem when considering whether the trust assets are property of the marriage for the purposes of sec 79 of the Act. In this regard the trust deed should be consulted, taking specific note of who is the settler, the trustee, appointor and the beneficiaries as well as the powers granted to the trustee and appointor. The trust deed will also contain the details as to distributions, variation of the deed and other instructions within the overarching trust legislation applicable to the particular jurisdiction (in Australia they are State based) that underlies the general principles of trusts (Ford et al, 2001). From a financial standpoint it is important to review the annual financial reports that show the trust income, capital and, historically, the pattern of distributions made to beneficiaries.

The trustee of a discretionary trust makes an annual determination as to which, if any, of the beneficiaries, receive a distribution of funds. In a service trust arrangement this usually follows the principle of tax minimisation including considerations of the net income of the beneficiaries, their current tax bracket, the ability to utilise franking credits and capital gains tax considerations. It is unusual for a service trust to hold onto undistributed income because it would attract the highest marginal tax rate. Similarly minors may also be at a disadvantage being subjected to the highest marginal tax rate over the minimal minor's threshold. There are a number of Family Court cases that have dealt with the issue of discretionary trusts in property proceedings.

Of concern to the Court in property decisions is the de facto control a party to the marriage has over the trust assets and whether that control is significant enough for trust assets to exceed being merely a resource for that person or to be considered as property of the marriage. In the marriage of Kelly (No 2), 1979, where the husband was not a beneficiary, settlor or appointor under the trust, it was considered that, where the husband had no legal or beneficial interest, "he husband could not assert any legal or equitable right in respect of them [the trust assets]" (Kennon and Spry, 2008). In Ashton v Ashton, 1986, where the husband was the appointor and a director of the trustee company, although not a beneficiary, the husband conceded that he exercised control of the trust. The Full Court held that "no person other than the husband has any real interest in the property or income of the trust except at the will of the husband." (Mellas, 2016). The husband's position as the appointor was seen to be de facto ownership of the trust as the husband had demonstrated his ability to change the trustee at his will (in order to remove the wife as a director of the trustee company).

.... having regard to the powers and discretion which the husband has, and having regard to what has in fact taken place, for the purposes of sec. 79, the husband's power of appointment, and all the attributes it carries with it, amounts to de facto ownership of the property of the trust.

Strauss J with the agreement of Ellis and Emery JJ 
In Goodwin and Goodwin Alpe, 1991, the Full court overruled the husband's argument that he merely held the power of appointing the trustee as a fiduciary power to be exercised for the benefit of the trust, and not any particular beneficiary (i.e. himself). In Davidson and Davidson, 1991, the trial judge, on noting that the husband had complete control of the corporate trustee, found that the trust was a creature of the husband. On appeal the Full Court agreed that the trust was operative at the will of the husband, notwithstanding the existence of a valid trust. The Full Court also went on to comment regarding the taxation purposes of the trust setup to the effect that:

As to the tax consequences, it appears to us that the Commissioner of Taxation could only impose tax if he avoided the trust. It is implicit in the findings of the learned trial judge that the trust is not a sham. This is our view also. His Honour therefore quite properly, did not take any possible tax consequences into account.

(Simpson, Murray and Nygh JJ)

In Harris and Harris, 1991, The Full Court considered the terms of the trust deed in light of the "relevant factual circumstances". It noted that the husband was the appointor and the guardian stating:

the husband had the fullest power of disposition over the property and the income of the trust, including the power to cause to have distributed to himself all its income and all its corpus. If he should choose to do so, no person could complain of any breach of trust. If the trustee were to be unwilling to carry out his 24 wishes, he could replace the trustee with another company which was in his effective control or any other person who would do his bidding. The very object of the Trust, as appearing from the instrument, was to put the husband, his appointor and guardian into the position of complete and unfettered control just as if he were the owner of the property. This arrangement was not a sham. It was a genuine transaction intended to bring about the legitimate income tax advantage and may have had other commercial motives.

(Ellis, Strauss and Lindenmayer JJ)

In conclusion the Court stated:

In our opinion, the husband's interest as a beneficiary under the Trust in combination with his rights and powers as appointor and guardian place him, for the purpose of section 79 of the Family Law Act into the position of an owner of property which property is constituted by his interest and his rights and powers under the Trust. This property is properly evaluated as equivalent to the value of the assets of the Trust. Under s 79 the court may make orders altering the interests of the parties in this property. If necessary, the court may require the husband to exercise his rights and powers under the Trust Deed so 
as to bring about a settlement of property out of the corpus or income of the Trust for the benefit of the wife."

In these cases the question of trust control by a party to the marriage has been considered directly, however, where a party to the marriage is not in control of the trust the Family Court has limited jurisdiction and cannot deprive third parties of an existing right (Ascot Investments Pty Ltd v Harper and Harper, 1981). There are a number of exceptions that require proof of fact, such as, if it can be established that one of the parties to the marriage actually has defacto control under the trust entity; if it can be shown that the trust is a sham; or if it can be shown that the trust is, in reality, an alter ego of a party to the marriage. (Mellas, 2016, p34). If a third party is a 'puppet' of a party to the marriage then that must be established as a matter of fact (Harris and Harris, 2011).

\section{Valuation of the Professional's Assets}

The predominant service trust structure (as outlined in diagram 1) would have in the attached family trust:

- an independent settlor who commenced the trust with a nominal sum and has no further role;

- A corporate trustee with the professional as a director, perhaps the sole director;

- The professional as the appointor;

- The professional as the guarantor;

- The professional as the nominated person for the establishment of the family association;

- Family beneficiaries that include the professional.

Legal discovery and disclosure should provide evidence for inspection including the trust deed, financial statements and a history of trust decisions that might indicate that one party is, in effect, in control of the trust, its assets and income. The valuer should refer to the material references in these documents underpinning any assumption of control the valuer has used (and stated) in their valuation report. It is important, however, to recognise that this is only an assumption (see APES 225 ) and that the decisions pertaining to control of a discretionary trust are the bailiwick of the legal profession, not the accountants.

The valuation of the professional's assets or ability to earn under a service trust arrangement is dissected into three components being:

1. The wage/salary earned either as an individual or a partner;

2. The proportional value held in the service business valued as an independent commercial business;

3. Any further assets held by the family trust other that the proportion of the service business considered in part 2.

\section{Market Value Check}

The predominant concept used in valuation for family law matters is the 'value to the owner' concept. This has been described as taking "into account the benefits to a particular owner even though this may not be based on a hypothetical third party purchaser" (Scott and Scott 2006; 
Reynolds and Reynolds, 1985). However in compiling a valuation report it is good practice to consider a market value check to see if it broadly confirms the theoretical construction in accordance with the value to the owner concept. With respect to placing a value on the commercial value of a service entity, as discussed in this paper, it is a logical check that, in fact, there is a market for the sale of service entity equity in common professional succession. For example, medical professionals commonly operate their practices within service trust structures and they commonly have practitioners leave the arrangement to be replaced by new practitioners.

Research of online business offerings confirms that medical practices attract a 'buy-in' amount paid by incoming practitioners. This buy-in amount is for the purchase of the practitioner's 'share' in the practice, that is, a share in the service entity that manages the practice. Whilst no research has been undertaken into the construction of the market value, the asking price for these shares appears to have a, sometimes considerable, intangible premium that exceeds the physical value of equipment and fit out. (medfin.com.au; businessview.com.au).

\section{Conclusion}

It is not uncommon for accountants or valuers to be called upon to advise the Court as to the financial status of a professional who has structured their income in a tax effective manner. Such financial structures may be legal and are available to high earning individuals who avail themselves of tax planning options within the law. One common economic structure used in Australia by professionals is known as a service trust or Phillips trust structure.

A service trust structure channels revenue from an individual taxpayer paying a high rate of tax to a service entity which is owned by a family trust whose beneficiaries are family members associated with the specified professional. This allows income to be legally distributed to family members who pay a far lower rate of tax, or are below the taxable threshold (pay no tax). As these beneficiaries do not have rights to the income of the family trust this may present a dilemma for the accounting valuation of the professional's net worth, particularly when required for family law distributions.

In this case the Courts have considered issues of control in order to establish a fair distribution of trust held assets. Valuers need to heed the Court's authority in this regard, contrary to accounting practice, whilst recognising that it is the Court that adjudicates on such matters, not the valuer. Other valuation issues such as professional goodwill require separate consideration within the financial structures and do not merely override the entity connections. The service entity within the structure should be valued according to its commerciality using an appropriate valuation methodology as it is, in of itself, alienable, that is, able to be separated, valued and if need be, sold. 
AABFJ | Volume 14, No.5, 2020

\section{References}

Ashton v Ashton, 1986, FLC 91 - 777

Accounting and Professional Ethical Standards Board, 2008, APES215, Forensic Accounting Services.

Accounting and Professional Ethical Standards Board, 2008, APES225, Valuation Services.

Australian Taxation Office, 1978, Taxation Ruling: Payments to service companies: splitting of professional income, IT 276

Australian Taxation Office, 2008, Practice Statement Law Administration, PS LA 2008/3, Provision of advice and guidance by the ATO.

Australian Taxation Office, 2006, TR 2006/2 Income tax: deductibility of service fees paid to associated service entities: Phillips arrangements.

Browne, M. 2016, The difference between tax minimisation and tax avoidance, Sydney Morning Herald, https://www.smh.com.au/money/tax/the-difference-between-tax-minimisationand-tax-avoidance-20160721-gqb4w9.html

Boucher, T. 2010, Blatant, Artificial and Contrived: tax schemes of the 70s and 80s, Civic, Canberra, A.C.T. Australian Taxation Office

Broun,M. and Fowler, S. 2016, Australian Family Law and Practice CCH

Businesses view.com, 2020, https://www.businessesview.com.au/businesses-forsale/health/medical-practice

Carmody, M. 2004, The Art of Tax Administration - Two Years on, 6th International Conference on Tax Administration, Sydney, 15 April

Commissioner of Taxation, 1991, Annual Report 1990-1991, Australian Taxation Office, Civic Australia

Duff and Duff, 1997, FLC 90-257

Federal Commissioner of Taxation v. Phillips, 19788 ATR 783; 78 ATC 4361; 1978, 36 FLR 399 (Phillips)

Ford, H. Lee, W. Bryan, M. Glover, J. Fullerton, I. 2001, The Law of Trusts Online. Thomson Reuters, Australia.

Garran, R, Sir. 1958, Prosper the Commonwealth, Angus and Robertson, Sydney.

Garry, D. 2019, An Overview of trusts in Australia accessed at https://www.davidgarry.com.au/overview-of-trusts-in-australia.html

Gartside v IRC, 1968, AC 553

Goodwin and Goodwin Alpe, 1991 
Fargher | Valuation and Service Trusts

Harris and Harris, 1991, 15 Fam LR 26

Harris and Harris, 2011, Fam CAFC 245

Hickey and Hickey, 2003, FLC 93-143

Investopedia, 2019, www.investopedia.com/terms

Janda, M. 2017, Trusts and tax minimisation explained, ABC News, https://www.abc.net.au/news/2017-07-28/trusts-and-tax-minimisationexplained $/ 8752480$

Jenkin, P. 2006, Tax Minimisation, The Australian Small Business Blog, ttps://www.australiansmallbusiness.net.au/2006/04/tax-minimisation.html

Kane, L. 2016, Strategies rich people use to pay less tax, Business Insider Australia, https://www.businessinsider.com.au/strategies-rich-people-use-to-pay-less-in-taxes2016-1\#/\#-1

Kennon v Spry, 2008, HCA 56, High Court Summaries

Legal Consolidated Barristers and Solicitors, 2019, Build your Service Trust Agreement https:/www.legalconsolidated.com.au/service-trust-agreement-intro/

Medfin.com, 2020, https://www.medfin.com.au/classifieds/practices-for-sale/medical

Mellas, J. 2016, When Family Law, Family Business and Trusts Collide, Geelong Law Society CPD Program, Melbourne, Victoria.

Pagone, G. 2010, Beyond "Blatant, Artificial and Contrived", Taxation Institute of Australia Lecture, Victorian State Library

Professionals Australia, 2019, Salary Packaging Guide, http://www.professionalsaustralia.org.au/financial-edge/tax-related-issues/

RE Weir's Settlement, 1969, 1 Ch 657

Reynolds and Reynolds, 1985 FLC 91-632

Scott and Scott 2006, FamCA 1379

Sainsbury v IRC 1970, Ch 712,

Stanford and Stanford, 2012, HCA 52

Tax Agent Services Act, 2009, Commonwealth of Australia.

Tax and Transfer Policy Institute, 2019, Progressive and Regressive Taxes, www.austaxpolicy.com/brief-progressive-and-regressive-taxes/

TaxEffective Accountants, 2020, https://www.taxeffective.com.au

The Family Law Act, 1975, Commonwealth of Australia 
AABFJ | Volume 14, No.5, 2020

Thomson Hall, 2019, Service trusts - a guide to their safe use -

https:/thomsonhall.com.au/wordpress/2010/07/service-trusts-a-guide-to-their-safe-use/ 